\title{
Effectiveness of using nest boxes as a form of bird protection after building modernization
}

\author{
Beata Dulisz ${ }^{1}$ D $\cdot$ Anna Maria Stawicka ${ }^{1} \cdot$ Paweł Knozowski ${ }^{1} \cdot$ Tom A. Diserens $^{2,3}$. \\ Jacek J. Nowakowski ${ }^{1}$
}

Received: 17 July 2020 / Revised: 22 October 2021 / Accepted: 6 November 2021 /

Published online: 24 November 2021

(c) The Author(s) 2021

\begin{abstract}
Modernization of urban buildings can decrease the availability of nesting sites in buildings, leading to sudden decreases in the density of avifauna. In this study, we investigated the use of nest boxes as a bird conservation measure after buildings were thermally modernized. In a 10 ha experimental area we mounted five types of nest boxes of different sizes and dimensions (a total of 132). Nest boxes were dedicated to species that lost access to their previous nesting sites. All species associated with the buildings significantly declined or disappeared. In the first year after the modernization, the House Sparrow (Passer domesticus) decreased by $66 \%$ compared with the period before the modernization, Eurasian Jackdaw (Corvus monedula) by 68\%, Common Starling (Sturnus vulgaris) by $70 \%$, and Common Swift (Apus apus) by $100 \%$. In the first two years after the modernization, the birds nested only in nest boxes. Five years of monitoring showed that using nest boxes as compensation for bird nesting sites lost during the renovation of buildings can cause a population to recover to ca. $50 \%$ of its original level. To optimize deployments of nest boxes, wildlife managers should consider target species' preferences for the dimensions and placement of boxes and limit the time boxes are used if a species prefers nesting outside nest-boxes, but in buildings (e. g. the House Sparrow) and does not require additional support.
\end{abstract}

Keywords Urban birds - Biodiversity conservation - Nest boxes · Building modernization · Urban planning

Communicated by Grzegorz Mikusinski.

Beata Dulisz

beata.dulisz@uwm.edu.pl

1 Faculty of Biology and Biotechnology, Department of Ecology and Environmental Protection,

University of Warmia and Mazury in Olsztyn, Plac Łódzki 3, 10-727 Olsztyn, Poland

2 Mammal Research Institute Polish Academy of Sciences, Stoczek 1, 17-230 Białowieża, Poland

3 Faculty of Biology, University of Warsaw, Miecznikowa 1, 02-089 Warsaw, Poland 


\section{Introduction}

Cities are home to many bird species, offering numerous breeding places within buildings and technical structures. Some species of urban avifauna only nest in man-made structures. These include, among others, species currently decreasing across Europe, such as the House Martin (Delichon urbicum), which is now listed as SPEC 2, and the House Sparrow (Passer domesticus) and Common Swift (Apus apus), listed as SPEC 3 (BirdLife International 2017). Kaisanlahti-Jokimäki et al. (2012) indicated that over $30 \%$ of bird communities living in cities and nearly $30 \%$ of birds inhabiting ski resorts were hole-nesters. Over $60 \%$ of all breeding pairs of species inhabiting old towns (city centers) and new housing estates with low vegetation diversity can use buildings for nesting (Dulisz and Nowakowski 1996). Populations of species that exploit urban environments can reach high densities and stable sizes. The population success (stable abundances, high survivorship, high fecundity) of urban-exploiters is also associated with other factors, such as the availability of additional food sources of anthropogenic origin, fewer predators, ameliorated climate, and milder winter conditions (Marzluff 2001).

Over the last 30 years, amid the economic transformation of Central and Eastern Europe, including Poland, the technologies used to construct new buildings and spatially plan housing estates have undergone great change. Existing buildings have also been subject to projects that improve their thermal efficiency on a large scale, partly as climate change mitigation efforts. As building facades are renovated, the openings, cavities, and chimneys in roofs, balconies, terraces, etc., that birds built nests in are filled. Although these developments limit the number of undesirable Feral Pigeons (Columba livia domestica) in the vicinity of humans, they also lead to population declines in other bird species (e.g. Schaub et al. 2016). Rosin et al. $(2016,2020)$ observed a similar pattern in rural settlements, where old estates hosted more species and individuals than new ones. At the village scale, their study found bird species richness and abundance were strongly negatively related with the percentage of new homesteads. The authors noted that as urban and suburban areas modernize, and rural settlements change type, with increasing numbers of new homesteads being unrelated to agricultural production, the availability of nesting sites gradually decreases for some species. This can have a dramatic impact on the abundance of birds nesting in buildings, and could therefore be an important and underestimated factor contributing to the decline in bird populations in European urban and agricultural landscapes.

Nest boxes can compensate for shortages of nesting sites in built-up areas. In past studies, nest boxes have mainly been introduced into urban environments with the aim of increasing the species richness of hole-nesters (Jokimäki 1999; Jokimäki et al. 2018; Reynolds et al. 2019). Hanging up different kinds of nest boxes in urban parks has been found to stimulate colonization by a great variety of hole-nesters, including threatened species (Jokimäki 1999; Jokimäki et al. 2018). They can also compensate for nest site loss in other anthropogenic environments, such as managed forests, and agricultural landscapes. By contrast, natural and old-growth forests contain high densities of holes, as trees host increasing numbers of holes as they age, grow and decline in health (Wesołowski and Martin 2018); observations in Białowieża Primeval Forest, Poland, an old-growth deciduous forest, showed that it is superabundant in holes (Wesołowski 2007). Nest boxes have compensated the following: breeding site losses due to the removal of dead or decaying trees in managed forests (Remm et al. 2006; Sánchez et al. 2007), scarcity of hollows due to lack of trees of large diameter (Camprodon et al. 2008), and natural damage to holes (Newton 
1994; Camprodon et al. 2008; Mazgajski 2009; Cockle et al. 2011). The introduction of nest boxes often leads to increases in the numbers of non-excavating hole-nesters (review in Newton 1998; Wiebe 2011). There are several examples of nest boxes being used as a conservation measure for secondary hole-nesters in agricultural areas and villages in cases where the availability of holes was the limiting factor: in Europe, the conservation programs of the Roller (Coracias garrullus) (Kovacs et al. 2008; Rodríguez et al. 2011; Kiss et al. 2017; Monti et al. 2019), Little Owl (Athene noctua) (Gottschalk et al. 2011) and Barn Owls (Tyto alba) (Johnson 1994); in Japan of the Dollarbird (Eurystomus orientalis) (Mine et al. 2014); and in the United States of the American Kestrel (Falco sparverius) (Katzner et al. 2005).

Recently, urban environments have begun to experience even further changes in the availability of nesting sites for the hole-nester guild: removal of old trees, changes in the structure of vegetation in towns, and the widespread adoption of new materials used to build modern buildings (often glass, steel), and modernization of buildings, often covering entire districts, deprive many species of nesting places in the cavities of buildings or in tree holes. But only a few studies from urban settlements have confirmed the effectiveness of nest boxes for species such as the Common Swift, Tree Sparrow (Passer montanus) and House Sparrow (Von Post and Smith 2015; Schaub et al. 2016). Generally speaking, nest boxes can be a good conservation measure if they are mounted in habitats with access to quality food, or if they provide the opportunity to shelter from predators or unfavorable weather conditions (e.g. roost places in winter or at night) (Sánchez et al. 2007; Mänd et al. 2009; Lima and Garcia 2016).

Mounting nest boxes on buildings as compensation for lost breeding sites is not without costs for developers. To ensure cost effectiveness, protection plans should comprise boxes with optimal dimensions, and consider the ultimate location, density and number of boxes. Regarding the dimensions, nest box size and shape should be optimised so as to be appropriate for the target species. A recent study in the city of Montpellier, France indicated that birds preferred medium and large nest boxes as roost sites in the prebreeding and breeding seasons, laid eggs more often in large and medium sized boxes, and avoided small boxes (Lambrechts et al. 2013). Mänd et al. (2009) pointed out that unused nest boxes may in fact indicate that boxes have been inappropriately distributed in space, rather than that an area has a surplus of breeding sites. Therefore, when using nest boxes as a conservation measure, it is important to know where birds are and what are their habitat preferences, as well as how readily a given species colonizes nest boxes as a substitute for natural holes and half-holes.

The present study tested a developer's compensation of nest sites lost during renovations. Our aim was to estimate the occupancy of nest boxes mounted for target species (the House Sparrow, Common Starling, Eurasian Jackdaw and Common Swift) in the five years following building modernization and the extent to which nest boxes contributed to population recovery. Our second aim was to verify the extent nest boxes preserve the composition and abundance of the bird assemblage in urban residential buildings after renovation of block facades on a large area of housing estate. 


\section{Methods}

The research was carried out in 2010-2016 in the city of Olsztyn (53 $\left.47^{\prime} \mathrm{N}, 20^{\circ} 30^{\prime} \mathrm{E}\right)$, NE Poland, in block-type residential buildings. The city $\left(88.33 \mathrm{~km}^{2}\right.$, ca. 175,000 inhabitants) is located in a lake district in the temperate climate zone with Atlantic and Baltic influences (average annual temperature $+7.2{ }^{\circ} \mathrm{C}$; average for July $+17{ }^{\circ} \mathrm{C}$; average for January $-3.5{ }^{\circ} \mathrm{C}$; average annual precipitation of $642 \mathrm{~mm}$, wind dominance from the west and north-west). The size of the research area within the housing estate was 10 ha. Buildings in the research area included 5- and 11-storey blocks of flats (total 25 buildings), general-purpose buildings, a few service facilities and typical communication infrastructure - parking lots, streets and other paved areas. Buildings occupied about $30 \%$ of the area, while the remaining part was arranged into green open spaces $(70 \%$ of the area), about $15 \%$ of which was dominated by bushes and trees (based on a land cover map; http://mapy.geoportal.gov.pl/imap). Population density of the housing estate was high ( 6895 people $\left./ \mathrm{km}^{2}\right)$. Buildings were between 25 and 30 years old. Some blocks of flats had gabled roofs, often used by birds, such as House Sparrows, Eurasian Jackdaws, Common Starlings, and Common Swifts as nesting sites, while other buildings had flat roofs, less frequently used by birds. In 2010, one year before the modernization planned for 2011, an inventory of the composition and abundance of avifauna nesting in buildings was carried out in the breeding season (from April 15 to July 15, 2010). A modified mapping method adapted to urban conditions was used (Tomiałojć 1980), with six morning and two evening censuses being conducted. Particular attention was paid to Common Swift control dates, whose presence in nests is most noticeable when they are feeding chicks, i.e. between June 20 and July 25. These dates correspond to the nestling period when swifts visit their nests most frequently (Arens 2011). During the census the buildings were observed with binoculars to detect all nest sites within their vicinity. The following bird behaviors were used as indicators of breeding: territorial singing, nest building, and young feeding. In the vicinity of the buildings prior to modernization, no bird nests boxes had been mounted on buildings, while four nest boxes for the Common Starling hung on trees nearby. As the birds were not marked individually, if a brood was recorded in the same place by the same species, the observation was treated as a single pair in our analysis.

In 2011, renovation works were carried out in the area, during which the buildings were thermally insulated (the walls were covered with polystyrene boards and mineral wool, while the flat roofs were filled with mineral wool pellets) and general construction works were carried out (installation of grilles for ventilation holes, fixing defects in the facade). During the renovation, the buildings were sealed, preventing bird access. All cavities in the walls, gaps under window sills, etc., were sealed with mortar; roof tiles, open vents and all other niches (window sills, balconies) were covered with a mesh. At the end of 2011, after the modernization was complete 132 nest boxes were hung up to compensate for lost breeding sites. Nest boxes were mounted on 16 buildings on which birds nested prior to the modernization, near to where nests had previously been found. Nest boxes for European Jackdaws were placed on chimneys on roofs or on walls at a height of 4 floors (height above the ground approx. 14-16 m), nest boxes for Common Swifts were mounted in groups of 2-3 under the roofs (approx. $14 \mathrm{~m}$ above the ground) and boxes for House Sparrows, Common Starlings and half-hole nesting birds on walls at the height of the 3rd-4th floors (i.e. 12-14 m). Boxes represented five types: HS - boxes for sparrows (51 boxes), $\mathrm{CS}$ - for starlings (10 boxes), EJ - for jackdaws (41 boxes), $\mathrm{S}$ - for swifts (26 boxes) and 
Table 1 Nest box types with the number of boxes mounted in the experimental area, dimensions of nesting boxes, and the number of boxes with an opening directed to the four compass points $(\mathrm{N}, \mathrm{E}, \mathrm{S}, \mathrm{W})$

Nest box type Dimensions of nesting boxes (m) (number of

boxes)
Number of boxes with an opening directed to four compass points

\begin{tabular}{|c|c|c|c|c|}
\hline Front heigh & Back height & Bottom size & $\begin{array}{l}\text { Hole diam- } \\
\text { eter }\end{array}$ & $\begin{array}{l}\text { Distance of } \\
\text { hole to bot- } \\
\text { tom }\end{array}$ \\
\hline
\end{tabular}

$\begin{array}{llll}\mathrm{N} & \mathrm{E} & \mathrm{S} & \mathrm{W}\end{array}$

\begin{tabular}{llllllrrrr}
\hline HS (51) & 0.26 & 0.29 & $0.13 \times 0.13$ & 0.035 & 0.195 & 10 & 31 & 7 & 3 \\
CS (10) & 0.34 & 0.37 & $0.14 \times 0.14$ & 0.05 & 0.25 & 6 & 1 & 2 & 1 \\
EJ (41) & 0.52 & 0.54 & $0.23 \times 0.23$ & 0.09 & 0.27 & 21 & 6 & 7 & 7 \\
S (26) & 0.14 & 0.14 & $0.38 \times 0.17$ & $0.035 \times 0.04$ & 0.10 & 6 & 2 & 15 & 3 \\
HO (4) & 0.09 & 0.16 & $0.12 \times 0.12$ & $0.12 \times 0.035$ & 0.09 & & 2 & 2 \\
Total 132 & & & & & & 43 & 42 & 31 & 16 \\
\hline
\end{tabular}
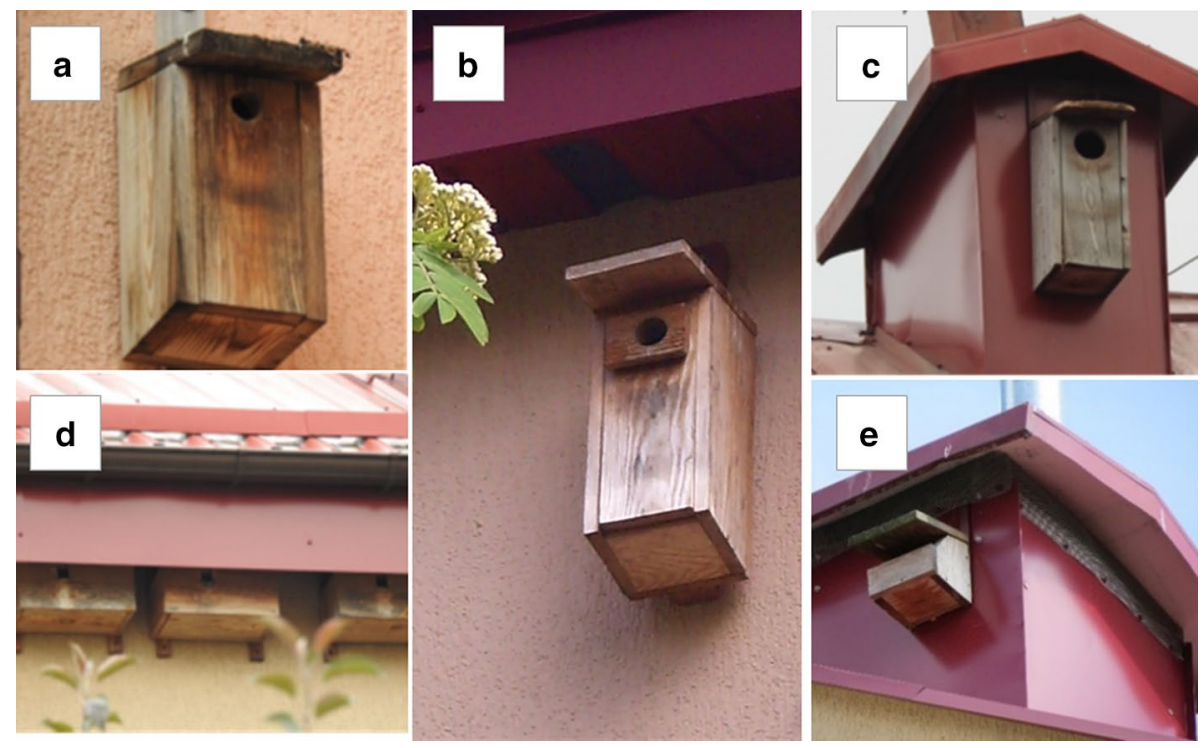

Fig. 1 Nest boxes used in the study: intended for the a House Sparrow (HS), b Common Starling CS), c Eurasian Jackdaw (EJ), d Common Swift (S), e half-hole birds (HO)

HO - half-open nest boxes for half-hole nesting birds (4 boxes). The boxes differed in size, shape and spatial arrangement on the building (Table 1 and Fig. 1).

In the study area, observations were carried out in five consecutive breeding seasons in 2012-2016, during which breeding of the species in the nest boxes, and in the area around the buildings, outside nest boxes were recorded. Based on the collected data, the following were determined: 
- the extent nest boxes contributed to sustaining the composition and abundance of building avifauna compared to the period before the modernization,

- the degree of occupancy of nest boxes by birds (both by the species for which the boxes were intended and by other species),

- the degree of occupancy in consecutive years of each type of box by the species for which it was intended,

- the degree of occupancy of nest boxes relative to their orientation,

- which species nested in buildings in the experimental area outside nest boxes.

Selectivity of the types of nest boxes used by birds was described using Jacobs' index (Jacobs 1974)

$$
\mathrm{D}=(\mathrm{r}-\mathrm{p}) /(\mathrm{r}+\mathrm{p}-2 \mathrm{rp})
$$

where: $\mathrm{r}$ - proportion a nest box type was inhabited by a species, and $\mathrm{p}$ - proportion a nest box type appeared in the study area.

The Jacobs index can range from -1 to +1 . A value of -1 means complete avoidance of a habitat, and a value of +1 indicates absolute preference. Values between -0.1 and +0.1 indicate that the habitat is neither preferred nor avoided. A chi square test (Sokal and Rohlf 2012) was used to test how the degree of occupancy of each type of nest box differed from the expected values resulting from their proportion in the environment and arrangement on buildings. Statistical analyses were carried out in Statistica 13.0 (TIBCO Software Inc. 2020). The type 1 error level was set at $p=0.05$.
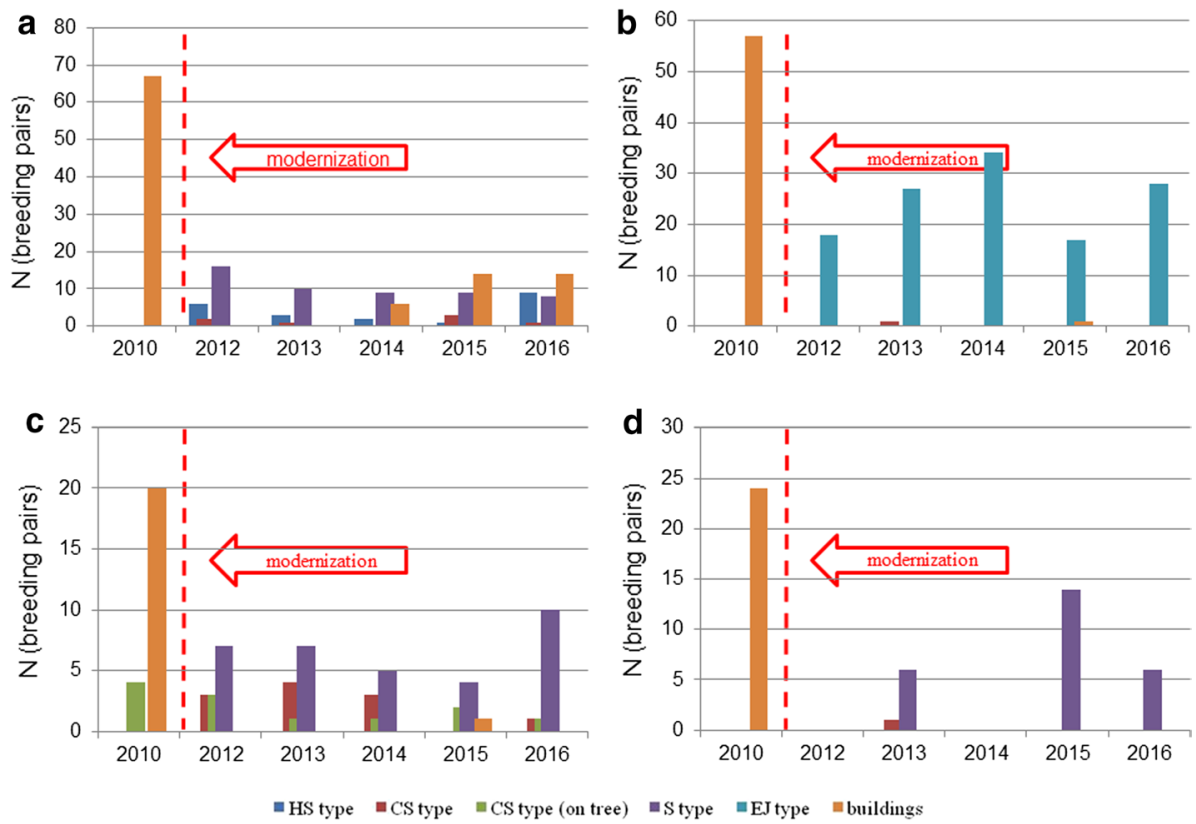

Fig. 2 The number of breeding bird pairs nesting in buildings and nest boxes before and after modernization (a - House Sparrow, b - Eurasian Jackdaw, c - Common Starling, d - Common Swift) 


\section{Results}

The abundances of species nesting within buildings before the modernization and after nest boxes were mounted during the 5-year experiment are shown in Fig. 2. In addition to these species, two pairs of White Wagtail (Motacilla alba) and one pair of Black Redstart (Phoenicurus ochruros), i.e. half-hole nesting birds, nested in the study area before the modernization. The dominant species at that time were the House Sparrow and Common Jackdaw. In the first breeding season after the modernization there was a large decrease in the number of breeding pairs on the buildings: House Sparrow abundance decreased by $66 \%$ compared with the period before modernization (Fig. 2a), the Eurasian Jackdaw by $68 \%$ (Fig. 2b), the Common Starling by $70 \%$ (Fig. 2c). Three species were absent in the first year after the modernization: the White Wagtail, Black Redstart and Common Swift (Fig. 2d). The presence of the half-hole nesting birds was not recorded over the five years of observation.

The abundance of the House Sparrow in the first year after the renovation (the first year of the experiment) was 23 breeding pairs, nesting only in nest boxes (Fig. 2a). It preferred the type $S$ box $(D=0.759)$. It also occupied a few nest boxes of type HS (the type targeted at sparrows) in the first year, and this number decreased over the following years (Fig. 2a). From the third year, the number of broods outside the boxes increased from 6 to 14 (Fig. 2a). The total number of House Sparrow breeding pairs in the 5th year of the experiment was about 50\% (32 breeding pairs; of which 18 pairs $-56 \%$ nested in nest boxes) of the population size prior to the modernization.

The number of Eurasian Jackdaws in the first year after the modernization decreased to about $30 \%$ of the level before the renovation (Fig. $2 \mathrm{~b}$ ). In the first three years of the experiment, the number of nest boxes used by this species increased.

Before the modernization, the Common Starling nested in buildings (20 breeding pairs), apart from four pairs that nested in boxes hung on trees. After the modernization, its population in subsequent breeding seasons decreased to the level of 7-13 breeding pairs, of which 1-3 pairs nested in boxes hung on trees. It preferred the type $S$ box $(D=0.745)$, the use of which increased in the last year of the experiment (Fig. 2c).

The Common Swift's nesting after the modernization was irregular (Fig. 2d). The species did not occur in the first and third year of the experiment; its abundance in other years varied. Except in one case, it nested exclusively in type $S$ boxes $(D=0.981)$.

Use of the different types of nest boxes in consecutive years is presented in Table 2 and Fig. 3. Type HS nest boxes, intended for the House Sparrow, were inhabited by four species over the five years (Fig. 3a). One of these species was the Eurasian Tree Sparrow (Passer montanus), which had not nested in the study area before the modernization. The Eurasian Tree Sparrow was the species that most often nested in this type of box, while the House Sparrow also frequently nested in it. In contrast, type CS nest boxes were mainly used by the Common Starling, for which the box was intended; one brood each of the House Sparrow, Common Swift and Eurasian Jackdaw were also recorded. Type S nest boxes, intended for the Common Swift, were occupied by three species, and almost half were House Sparrow broods -52 broods, followed by the Common Starling - 33 broods and the Common Swift - 26 broods (Fig. 3b). Only one S nest box was never occupied over the 5-year period. Nest boxes of the type EJ were occupied exclusively by the species for which they were intended, the Eurasian Jackdaw. In each of the boxes of this type, breeding occurred at least once over the analyzed period. 


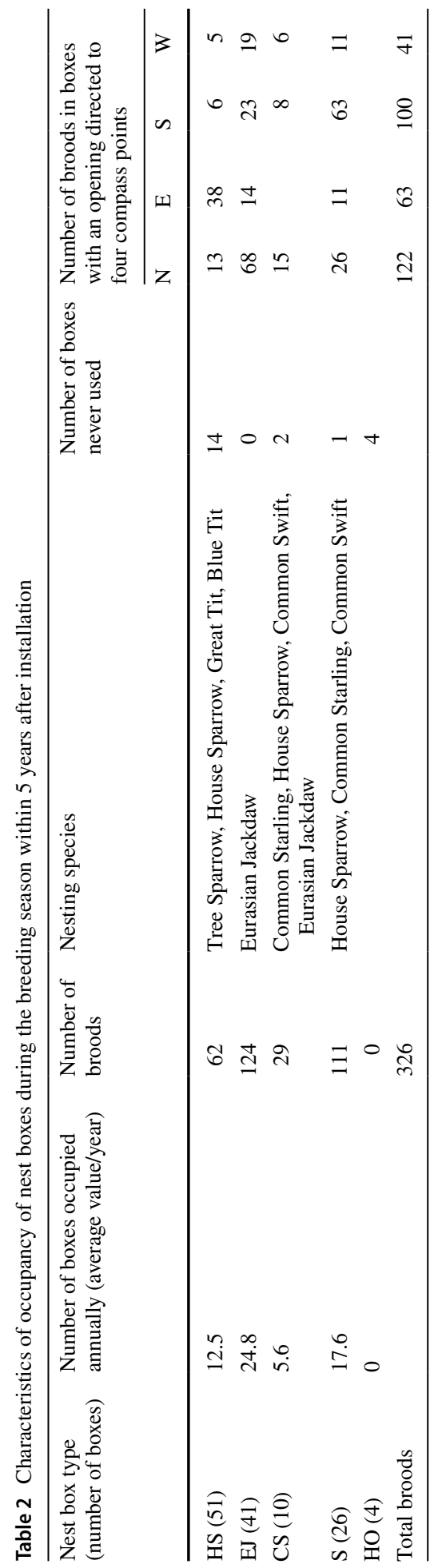



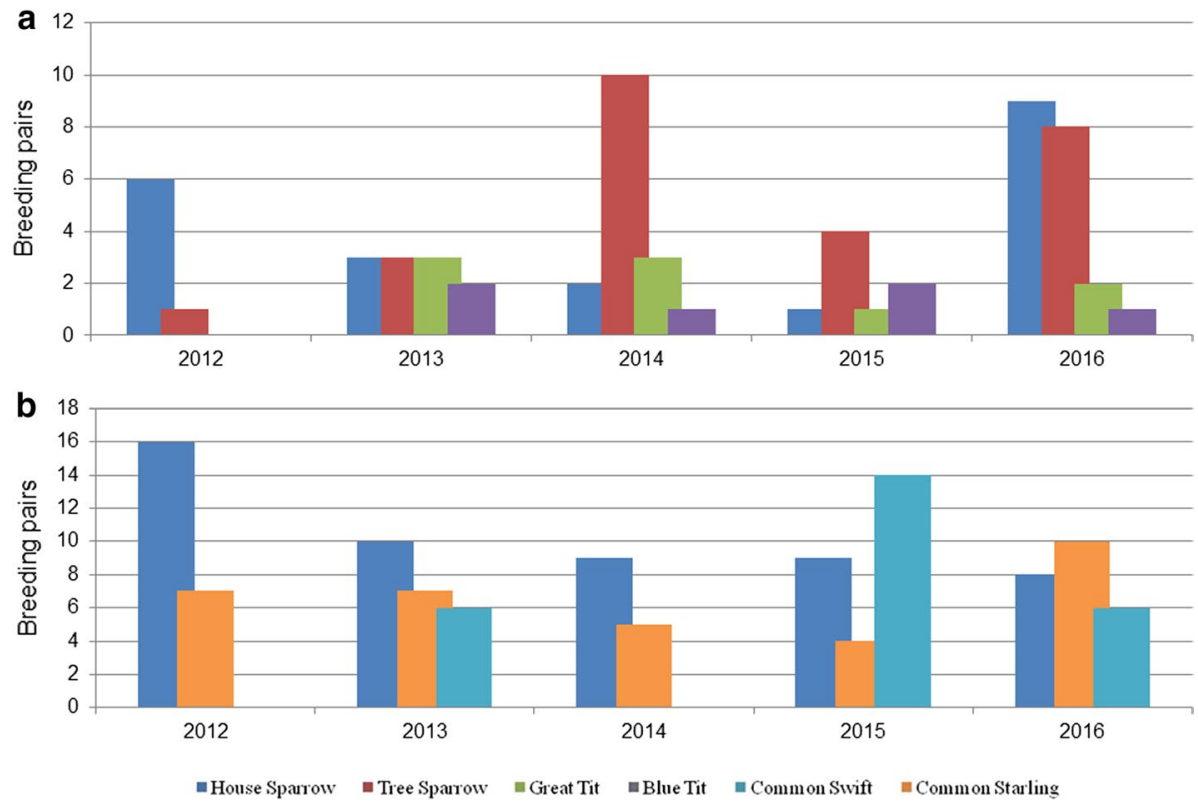

Fig. 3 Occupancy of the type HS nest box, intended for the House Sparrow (a) and the type S nest box, intended for the Common Swift (b) by various bird species

Table 3 Jacobs coefficients characterizing the selectivity of individual types of nest boxes by birds

\begin{tabular}{lcccr}
\hline Species & Nest box HS & Nest box CS & Nest box EJ & Nest box S \\
\hline House sparrow & -0.300 & 0.063 & -1.000 & $\mathbf{0 . 7 5 9}$ \\
Tree sparrow & $\mathbf{0 . 9 5 0}$ & -0.375 & -1.000 & -1.000 \\
Common starling & -1.000 & $\mathbf{0 . 7 4 3}$ & -1.000 & $\mathbf{0 . 7 4 5}$ \\
Great tit & $\mathbf{1 . 0 0 0}$ & -1.000 & -1.000 & -1.000 \\
Blue tit & $\mathbf{1 . 0 0 0}$ & -1.000 & -1.000 & -1.000 \\
Common swift & -1.000 & -0.375 & -1.000 & $\mathbf{0 . 9 8 1}$ \\
Eurasian jackdaw & -1.000 & -0.826 & $\mathbf{0 . 9 9 2}$ & -1.000 \\
\hline
\end{tabular}

The values of the Jacobs coefficient range between the value -1 (complete avoidance), to the value +1 (complete selectivity). Positive values of the Jacobs coefficient $>0.7$ (in bold) indicate selectivity of specific breeding boxes. The value of the Jacobs coefficient cannot be tested, it is only an interpretation of its value

The selection of the different types of nest boxes by birds is presented in Table 2 . Apart from two species, the House Sparrow and Common Starling, birds nested in boxes of the types intended for them, avoiding or sporadically nesting in other types. By contrast, the House Sparrow and Common Starling showed a clear preference for box type $\mathrm{S}$ intended for the Common Swift, with the House Sparrow showing a particularly strong preference for it (Table 3). Both species occupied significantly different types of nest boxes than expected (House Sparrow: $\mathrm{chi}^{2}=108.168$, df $=3, \mathrm{p}<0.001$; Common Starling, $\left.\mathrm{chi}^{2}=140.116, \mathrm{df}=3, \mathrm{p}<0.001\right)$. 
Birds did not select nest boxes depending on the orientation of the entrance. The number of broods in boxes with different orientations $(\mathrm{N}, \mathrm{E}, \mathrm{W}, \mathrm{S}$ ) was random (chi-square test, $\mathrm{df}=3$, type HS: $\mathrm{p}=0.728$, type $\mathrm{EJ}: \mathrm{p}=0.649$, type $\mathrm{CS}: \mathrm{p}=0.061$, type $\mathrm{S}: \mathrm{p}=0.804$ ).

\section{Discussion}

In this study, nest boxes were introduced to replace lost nesting places in buildings after renovation of their facades, during which all the cavities in walls and ventilation outlets were permanently sealed and the buildings became inaccessible to birds. In the first two years all broods occurred only in nest boxes hung on the buildings. The modernization of the buildings led to a clear decrease in the number of birds nesting in them. In the first year after the modernization, the numbers of birds inhabiting the nest boxes constituted approx. $30-40 \%$ of the population sizes before the renovation works. Two species did not nest at all - the White Wagtail and Black Redstart. The nest boxes therefore partially preserved the building associated avifauna of the housing estate. Our experiment shows nest boxes are an effective conservation measure for preserving species that nest on buildings (the Eurasian Jackdaw, Common Starling, House Sparrow, Common Swift and Eurasian Tree Sparrow). In addition, the experiment showed birds can easily adapt to the use of nest boxes, which were not available on the estate before the modernization.

The depletion of nesting sites as a consequence of the gradual replacement of old buildings with new ones, which are often built with modern materials, leads to decreases in bird population sizes, especially of those nesting in cavities (Moudrá et al. 2018; Rosin et al. 2016, 2020). Mainwaring et al. (2015) reported that residential buildings (houses or blocks of flats) are often nesting places for species such as the Common Swift, Common Starling and House Sparrow, which nest in the eaves of houses. Newly constructed buildings without cracks and with smooth walls limit nesting opportunities (Angelier and Brischoux 2019), as do modernized buildings. These types of buildings that prevent bird access are often located in estates whose residents are of a high socioeconomic status (Shaw et al. 2008). As built-up areas in cities modernize, renovations cause many buildings to cease to play a role as an alternative for secondary hole-nesters, which is especially visible in estates that host few trees with natural holes or nest boxes. Measures that increase the energy efficiency of buildings and quality of life of their inhabitants, alongside new trends in architecture, limit biodiversity as they reduce the availability of nesting or foraging sites. This conflict between two goals of sustainable development - on the one hand, protection of biodiversity and, on the other, climate mitigation through better insulation of buildings, was also pointed out by Rosin et al. (2020). Just as old villages are hotspots of biodiversity (Rosin et al. 2016, 2020), city centers are important conservation areas, especially for endangered bird species from the hole-nester guild, with major populations reproducing in cities, e.g. of the House Sparrow, Common Swift and House Martin (Delichon urbicum) (Jokimäki et al. 2018). Studies have noted that seeing and hearing birds improves people's self-esteem and well-being (Nilsson and Berglund 2006; Annerstedt et al. 2013; Tryjanowski and Murawiec 2021). People have been found to particularly value the aesthetics of birds and their role in urban ecosystems (Hedblom et al. 2017). Residents appear to value the ecosystem services provided by birds relative to levels of perceived bird species richness (Belaire et al. (2015). Perhaps one of the most important roles of birds in cities is to link city dwellers to the wider environment. These values provided by birds can be 
regarded as a cultural ecosystem service (Hedblom et al. 2017) and should be considered when planning sustainable cities.

Tomasevic and Marzluff (2017) showed that in the most heavily urbanized areas, classed as those with below $12 \%$ forest cover on a $1 \mathrm{~km}^{2}$ scale, secondary hole-nesters nested primarily in places of anthropogenic origin, using nest boxes or platforms (59\% of broods). Thus, when designing buildings, modern architects should account for the habitat needs of hole-nesting species, and urban planners should preserve old trees with holes or, alternatively, introduce nest boxes to the environment to support the occurrence of endangered hole nesting birds (Jokimäki et al 2018; Callaghan et al. 2021). Rosin et al. (2020) suggested that urban designers and architects should draw inspiration from traditional architecture and include different types of nest boxes in their plans.

Of the five types of nest boxes introduced into the environment as compensation for lost nest sites after building modernization, type $S$ boxes, intended for the Common Swift, were the most often inhabited. They were inhabited by three species of birds - the House Sparrow, Common Starling and Common Swift. Also inhabited to a high degree were EJ nest boxes, regularly used by Eurasian Jackdaws, the species for which this box type was intended. CS nest boxes, dedicated to Common Starling, were $40-80 \%$ occupied by this species, and HS nest boxes, intended for the House Sparrow were occupied at a level of 14-39\%, by the Eurasian Tree Sparrow, House Sparrow and two tit species - the Great Tit (Parus major) and Blue Tit (Cyanistes caeruleus).

The degree nest boxes are occupied may depend on the plasticity of species when choosing sites, as well as the opportunities for finding alternative nesting sites. In our research, hanging up nest boxes was an effective form of bird protection, but the different bird species colonized nest boxes in successive years to varying degrees, and each preferred certain types of nest boxes - factors which affected the recovery of the species' populations.

A high proportion of broods in nest boxes and a gradual increase in colonization rates in successive years were observed in the Common Starling and Eurasian Tree Sparrow. The Common Starling seems to adapt well to nesting in alternative places. Heldbjerg et al. (2017) also found starlings occupied a high proportion of nest boxes mounted on utility buildings or nearby trees. The Eurasian Tree Sparrow, which had previously not nested in the buildings of this estate, appeared and inhabited nesting boxes on the estate during the research period, and this could be related to the upward population trend recorded in this species throughout the country since 2012 (Chylarecki et al. 2018).

The Eurasian Jackdaw's occupancy of boxes increased each year till the third year, and then decreased. A decrease in the occupancy of nest-boxes in successive years was also observed in the House Sparrow. A similar decrease in the number of jackdaws nesting in nest boxes in successive years was observed in another study, where the authors suggested that the decrease could have been due to low breeding success in a few years and a deterioration in the quality of nest boxes (Czechowski et al. 2013). Over time, boxes deform and crack, allowing rainwater to penetrate. In many cases, jackdaw nest boxes have helped preserve populations, i.e. their stabilization, or even expansion (Antikainen 1999; Schmidt 1999; Flöter et al. 2006; Unger and Kurth 2010; Koop and Berndt 2014; Rubenser 2012). Sometimes jackdaws take several years to become accustomed to nest boxes (Eisermann and Börner 2006; Koop and Berndt 2014). A study in Vienna found that in the first years after renovation, jackdaws readily occupied chimney boxes but not regular nest boxes (HoiLeitner et al. 2016). Their previous habit of nesting in chimneys is probably what determined which of these artificial nesting sites was chosen.

The House Sparrow, at first nested only in boxes, but with time since modernization showed a clear tendency to prefer nesting in the buildings outside the boxes; gaps gradually 
appeared in the wall insulation (mainly polystyrene) and under tiles, which the House Sparrow began to nest in. Research in 60 small urban settlements with moderate levels of urbanization $25 \mathrm{~km}$ from the center of Prague, the Czech capital, found that the House Sparrow preferred nesting in old buildings rather than in newly built areas (Moudrá et al. 2018). Sparrows were present in all areas with old buildings, while only in $71 \%$ of areas with new buildings. Von Post and Smith (2015) observed that although artificial nest boxes increase opportunities for sparrow nesting, they have not been proven to lead to increases House Sparrow numbers. As buildings aged, sparrows appeared to prefer nesting under roofs and used nest boxes less frequently, as observed in our study.

The occupancy of nest boxes in successive years, and thus the recovery of the bird populations, may be have been partly a result of the availability of favorable nesting places in the vicinity on unmodernized buildings. The Common Swift left the estate in the 2011 breeding season during the renovation works as this species displays nest-site fidelity (Cramp 1985) and the returning swifts could not access the buildings. Even though the nest boxes were hung in the same places as where the birds nested before, as suggested by Scholl (2004), in the years following the renovation the Common Swift reached slightly over $50 \%$ of the number of pairs before the modernization. The low occupancy after the renovation may also have resulted from negative population trends in this region of Poland (Chylarecki et al. 2018), or from the swifts having moved to other nearby housing estates with available breeding sites. Because swifts need time to detect potential nesting sites, especially when existing colonies are located far away (Arens 2004), box occupancy gradually increases in the years after renovations (Schaub et al. 2016). Type $S$ nest boxes, mounted externally on buildings near the roof edge, seem to match the swift's preferred location (Schaub et al. 2016), and inlet shape and size. However, the Common Swift only colonized type $\mathrm{S}$ boxes to a limited degree, as this box was often occupied by two non-target species (Common Starling, House Sparrow), whose breeding precedes that of the Common Swift, which arrives later to nest sites. Successive breeding of three species in the same season occurred in several nest boxes. Competition for nest-boxes between species that arrive or breed at different times is a well-known phenomenon (e.g. Slagsvold 1975; Minot and Perrins 1986; Charter et al. 2013; Milligan and Dickinson 2016; Goldshtein et al. 2018; Ye et al. 2019). In several cases, a pair of sparrows shared a nest box with a pair of swifts when their breeding times overlapped. Similar sharing of nest boxes by the Common Swift and Black Redstart was observed by Pirio et al. (2015). When breeding together these species build separate nests in two corners of a box.

The Common Starling and House Sparrow preferred type $\mathrm{S}$ boxes. In comparison to HS and CS nest boxes, the $\mathrm{S}$ nest box had a larger bottom surface area, and its entrance was located asymmetrically on the front wall. The size of $S$ type nest boxes may correspond to the preferences of the Common Starling and House Sparrow. Mazgajski (2003) showed that the Common Starling prefers to use deeper boxes, and when excessive nest material accumulates inside the box, birds remove it themselves. This causes the distance between the nest inside the box and the entrance to increase. Common Starlings have also been found to prefer boxes with round (Coleman 1974) and smaller entrances (Lumsden 1976). This behavior may be an imprinted typical anti-predator adaptation that limits the opportunities for a predator to penetrate the nest (Wesołowski and Martin 2018). Several studies in forests have found that nests situated closer to entrances are depredated more frequently (Czeszczewik and Walankiewicz 2003; Wesołowski and Rowiński 2012; Maziarz et al. 2015). Other studies have reported similar nesting preferences in the Common Starling, finding that they selected deeper boxes with a larger bottom area and volume (Jackson and Jackson 2016), and with openings in the front wall (Flux and Flux 1981). Also, the studies 
of Perrins (1979), Lowther (2012), and Lambrechts et al. (2013) suggested that the House Sparrow also prefers medium and large nest boxes, especially with a large bottom area for roosting and nesting.

It is noteworthy that we hung up S-type nest boxes in groups of 2-3 right under rooves, and it cannot be ruled out that this created a favourable environment for colony nesting, which may have played an important role in the Common Starling, House Sparrow, and Eurasian Tree Sparrow. In favourable locations, these species often nest in colonies, which may be important for reducing predation risk, information exchange and collective foraging (Anderson 2006).

The use of nest boxes as a conservation measure should be preceded by a detailed evaluation about whether they are really needed in the environment. Nest boxes are only useful when the number of potential nesting sites is limited (Altwegg et al. 2014), otherwise they can act as ecological traps (Demeyrier et al. 2016; Jokimäki et al. 2018; Kettel et al. 2018; Sumasgutner et al. 2014a, b). Other authors have noted that prior to using nest boxes as a conservation measure the following should be assessed: i) whether nest building materials are available, ii) whether local environmental conditions positively correlate with the reproductive biology of target species (Greenwood 2007), and iii) whether the location and distribution of nest boxes match the appropriate habitats and optimal distances in intra- and interspecific relationships (Milligan and Dickinson 2016; Deeming et al. 2017). Bird protection guides often suggest hanging nest boxes in a specific direction. In our research, birds did not show a preference for nest boxes with entrances with a particular orientation. Many studies around the world have shown that the orientation of bird nests depends on local climate variables such as temperature, wind and precipitation (reviewed in e.g. Schaaf et al. 2019; Schaaf and de la Peña 2020). In temperate regions, closed nest-building birds tend to point their nest entrance towards the sun to raise the temperature inside the nests. Perhaps in an urban environment birds show no particular preference as the local area acts as a "heat island" with wind directions dependent on the configuration of the buildings in the vicinity.

Periodic cleaning of nest boxes is important to reduce the prevalence of parasites that can cause birds to abandon breeding sites. A few studies have found that various songbirds prefer to nest in clean nest boxes than in used ones (Merino and Potti 1995; Johnson 1996; Stanback and Dervan 2001). Propagating urban greenery by planting deciduous trees is important for preserving breeding populations of the House and Eurasian Tree Sparrows, Common Starling, Great and Blue Tits and Eurasian Jackdaw, as it leads to the formation of natural holes. Deciduous forests have been found to have a greater abundance of potential nest cavities as well as greater food availability than coniferous woodlands (Van Balen et al. 1982; Newton 1998; Riddington and Gosler 1995). Also, as suggested by Serrano-Davies et al (2017), in nest-box provisioning it is important to consider the habitat traits around the nesting sites, such as the heterogeneity of vegetation structure, tree height, and succession stage of the shrubs. We think that a good approach to protecting birds in cities is to establish patch-matrix corridors with natural food resources in patches and semi-natural tall vegetation between settlements.

The findings presented in this study investigating the use of nest boxes for the conservation of selected bird species whose nesting sites were limited by modernization of residential buildings allow us to draw the following conclusions:

1. In the first years after modernization, birds readily used nest boxes as breeding places, and boxes may have been the only breeding sites available; nesting outside the boxes was 
not found, and not all boxes were used. In the first year after modernization, the number of breeding pairs was 60-70\% lower compared to the period before modernization.

2. The dimensions of boxes (the types of boxes) can influence how readily different species occupy them. Three bird species in a similar body size class-the House Sparrow, Common Starling and Common Swift-preferred boxes with a larger bottom surface area.

3. For the House Sparrow, it may be important to plan nest-box groups (similar to the S-type nest-box groups tested in this work) to enable semi-colonial nesting. This approach could be a more effective conservation measure than hanging up nest boxes solitarily. In future, this topic should be studied in more detail in a well-defined experiment that compares the colonizing of single and groups of nest-boxes.

4. The use of nest boxes guarantees the rebuilding of local populations (at least partially). This study observed a slow increase in the number of species in successive years of the experiment, but found that the rate of box use by different species varied. The House Sparrow had a clear preference for nesting outside the boxes. In the Eurasian Jackdaw, an upward trend came to a halt, probably due to the deterioration of the boxes' quality.

5. To optimize the cost-effectiveness of using nest boxes as a conservation measure the following are important:

a. Properly estimating the appropriate number of boxes to introduce into the environment;

b. Taking into account the preferences of target bird species for boxes of certain dimensions;

c. Ensuring boxes are maintained and sanitary;

d. Limiting the time boxes are used if a species prefers nesting outside and does not require support.

6. Future studies should investigate how modern building designs and renovations can be adapted to ensure opportunities for birds to nest directly within buildings to alleviate the necessity for providing nest boxes.

Open Access This article is licensed under a Creative Commons Attribution 4.0 International License, which permits use, sharing, adaptation, distribution and reproduction in any medium or format, as long as you give appropriate credit to the original author(s) and the source, provide a link to the Creative Commons licence, and indicate if changes were made. The images or other third party material in this article are included in the article's Creative Commons licence, unless indicated otherwise in a credit line to the material. If material is not included in the article's Creative Commons licence and your intended use is not permitted by statutory regulation or exceeds the permitted use, you will need to obtain permission directly from the copyright holder. To view a copy of this licence, visit http://creativecommons.org/licenses/by/4.0/.

\section{References}

Altwegg R, Jenkins A, Abadi F (2014) Nestboxes and immigration drive the growth of an urban Peregrine Falcon Falco peregrinus population. Ibis 156(1):107-115. https://doi.org/10.1111/ibi.12125

Anderson TR (2006) Biology of the Ubiquitous House Sparrow. From Genes to Populations. Oxford Univ. Press, New York

Angelier F, Brischoux F (2019) Are house sparrow populations limited by the lack of cavities in urbanized landscapes? An Experimental Test. J Avian Biol 50(3):1-6. https://doi.org/10.1111/jav.02009 
Annerstedt M, Jönsson P, Wallergård M, Johansson G, Karlson B, Grahn P, Hansen ÅM, Währborg P (2013) Inducing physiological stress recovery with sounds of nature in a virtual reality forest-Results from a pilot study. Physiol Behav 118:240-250. https://doi.org/10.1016/j.physbeh.2013.05.023

Antikainen E (1999) Effects of protection on the population dynamics of the Jackdaw (Corvus monedula) in Finland. M Verein Sächsisch Ornithol 8(2):9-20

Arens H (2004) Gelungene Ansiedlung von Mauerseglern an einem Einfamilienhaus (Successful settlement of swifts on a single-family house). Der Falke 51:51

Arens H (2011) Breeding biology of a pair of Swifts Apus apus ringed with an attached transponder. Vogelwelt 132:153-160

Belaire JA, Westphal LM, Whelan CJ, Minor ES (2015) Urban residents' perceptions of birds in the neighborhood: Biodiversity, cultural ecosystem services, and disservices. Condor 117(2):192-202. https:// doi.org/10.1650/CONDOR-14-128.1

BirdLife International (2017) European birds of conservation concern: populations, trends and national responsibilities. BirdLife International, Cambridge

Callaghan CT, Poore AGB, Major RE, Cornwell WK, Wilshire JH, Lyons MB (2021) How to build a biodiverse city: environmental determinants of bird diversity within and among 1581 cities. Biodivers Conserv 30(1):217-234

Camprodon J, Salvanyà J, Soler-Zurita J (2008) The abundance and suitability of tree cavities and their impact on hole-nesting bird populations in beech forests of NE Iberian Peninsula. Acta Ornithol 43(1):17-31. https://doi.org/10.3161/000164508X345293

Charter M, Leshem Y, Izhaki I (2013) Asymmetric seasonal nest site competition between Great Tits and House Sparrows. J Ornithol 154:173-181. https://doi.org/10.1007/s10336-012-0884-5

Chylarecki P., Chodkiewicz T., Neubauer G., Sikora A., Meissner W., Woźniak B., Wylegała P., Ławicki Ł., Marchowski D., Betleja J., Bzoma S., Cenian Z., Górski A., Korniluk M., Moczarska J., Ochocińska D., Rubacha S., Wieloch M., Zielińska M., Zieliński P., Kuczyński L. 2018. Trendy liczebności ptaków w Polsce. GIOŚ, Warszawa

Cockle KL, Martin K, Wesołowski T (2011) Woodpeckers, decay, and the future of cavity - nesting vertebrate communities worldwide. Front Ecol Environ 9(7):77-382. https://doi.org/10.1890/110013

Coleman JD (1974) The use of artificial nest sites erected for starlings in Canterbury. New Zealand New Zeal J Zool 1(3):349-354. https://doi.org/10.1080/03014223.1974.9517841

Cramp S (ed) (1985). Handbook of the birds of Europe, the Middle East and North Africa. Vol. 4: Terns to woodpeckers. Oxford University Press, Oxford

Czechowski P, Bocheński M, Ciebiera O (2013) Decline of Jackdaws Corvus monedula in the city of Zielona Góra. Int Stud Sparrows 37:32-36. https://doi.org/10.1515/isspar-2015-0023

Czeszczewik D, Walankiewicz W (2003) Natural nest sites of the Pied Flycatcher Ficedula hypoleuca in a primeval forest. Ardea 91:221-230

Deeming DC, Biddle LE, DuFeu CR (2017) Interspecific and intraspecific spatial separation by birds breeding in nestboxes. Avian Conserv Ecol 12(2):1. https://doi.org/10.5751/ACE-01026-120201

Demeyrier V, Lambrechts MM, Perret P, Grégoire A (2016) Experimental demonstration of an ecological trap for a wild bird in a human-transformed environment. Anim Behav 118:181-190. https://doi.org/ 10.1016/j.anbehav.2016.06.007

Dulisz B, Nowakowski JJ (1996) The species diversity of the avifauna in built-up areas in the city of Olsztyn (NE Poland). Acta Ornithol 31(1):33-38

Eisermann K, Börner J (2006) Populations ökologie und Auswirkungen von Manipulationen des Nistplatz angebotes an einer Brutkolonie der Dohle (Corvus monedula) in Chemnitz (Population ecology and effects of manipulation of the nesting site on a jackdaw breeding colony (Corvus monedula) in Chemnitz). M Verein Sächsisch Ornithol 9:611-622

Flöter E, Saemann D, Börner J (2006) Brutvogelatlas der Stadt Chemnitz (Breeding bird atlas of the city of Chemnitz). M Verein Sächsisch Ornithol 9(4):5-306

Flux JEC, Flux MM (1981) Population dynamics and age structure of starlings (Sturnus vulgaris) in New Zealand. New Zeal J Ecol 4:65-72

Goldshtein A, Markman S, Leshem Y, Puchinsky M, Charter M (2018) Nest-site interference competition with House Sparrows affects breeding success and parental care in Great Tits. J Ornithol 159(3):667673. https://doi.org/10.1007/s10336-018-1541-4

Gottschalk TK, Ekschmitt K, Wolters V (2011) Efficient placement of nest boxes for the little owl (Athene nосtиa). J Raptor Res 45(1):1-14. https://doi.org/10.3356/JRR-09-11.1

Greenwood JJD (2007) Citizens, science and bird conservation. J Ornithol 148(1):77-124. https://doi.org/ 10.1007/s10336-007-0239-9 
Hedblom M., Knez I., Gunnarsson B. (2017) Bird diversity improves the well-being of city residents. In: Murgui E, Hedblom M [ed] Ecology and Conservation of Birds in Urban Environments. Springer, pp 287-306

Heldbjerg H, Fox AD, Thellesen PV, Dalby L, Sunde P (2017) Common Starlings (Sturnus vulgaris) increasingly select for grazed areas with increasing distance-to-nest. PLoS ONE 12(8):1-17. https:// doi.org/10.1371/journal.pone.0182504

Hoi-Leitner M, Wiedenegger E, Hille S (2016) Jackdaws (Corvus monedula) in Vienna: Status and conservation of nest-sites. Vogelwarte 54:73-81

Jackson JA, Jackson BJS (2016) Dynamics of Woodpecker - Common Starling interactions: a comparison of Old World and New World species and populations. Ornis Hungarica 24(1):1-41. https://doi.org/10. 1515/orhu-2016-0001

Jacobs J (1974) Quantitive measurement of food selection. Oecologia 14:413-417

Johnson PN (1994) Selection and use of nest sites by barn owls in Norfolk, England. J Raptor Res 28:149-153

Johnson LS (1996) Removal of old nest material from the nesting sites of house wrens: effects on nest site attractiveness and ectoparasite loads. J Field Ornithol 67:212-221

Jokimäki J (1999) Occurrence of breeding bird species in urban parks: effects of park structure and broadscale variables. Urban Ecosyst 3:21-34. https://doi.org/10.1023/a:1009505418327

Jokimäki J, Suhonen J, Kaisanlahti-Jokimäki MJ (2018) Urban core areas are important for species conservation: a European-level analysis of breeding bird species. Landscape Urban Plan 178:73-81. https:// doi.org/10.1016/j.landurbplan.2018.05.020

Kaisanlahti-Jokimäki MJ, Jokimäki J, Huhta E, Siikamäki P (2012) Impact of Seasonal Small-scale Urbanization on Nest Predation and Bird Assemblages at Tourist Destination. In: Lepczyk CA, Warren PS (ed) Urban Bird Ecology and Conservation. Studies in Avian Biology (no 45), University of California Press, Berkeley, CA, pp 93-110

Katzner T, Robertson S, Robertson B, Klucsarits J, McCarty K, Bildstein KL (2005) Results from a longterm nest-box program for American Kestrels: implications for improved population monitoring and conservation. J Field Ornithol 76:217-226

Kettel EF, Gentle LK, Quinn JL, Yarnell RW (2018) The breeding performance of raptors in urban landscapes: a review and meta-analysis. J Ornithol 159:1-18. https://doi.org/10.1007/s10336-017-1497-9

Kiss O, Tokody B, Ludnai T, Moskát C (2017) The effectiveness of nest-box supplementation for the conservation of European rollers (Coracias garrulus). Acta Zool Acad Sci H 63(1):123-135. https://doi. org/10.17109/AZH.63.1.123.2017

Koop B, Berndt RK (ed) (2014) Vogelwelt Schleswig-Holsteins. Band 7. Zweiter Brutvogelatlas (Birds of Schleswig-Holstein. Volume 7. Second breeding bird atlas). Wachholtz Verlag, Neumünster, Germany

Kovacs A, Barov B, Orhun C, Gallo-Orsi U (2008) International Species Action Plan for the European Roller Coracias garrulus garrulus. European Commission. https://ec.europa.eu/environment/nature/ conservation/wildbirds/action_plans/docs/coracias_garrulus_garrulus.pdf.

Lambrechts MM, Abouladzé M, Bonnet M, Demeyrier V, Doutrelant C, Faucon V, le Prado G, Lidon F, Noell T, Pagano P, Perret P, Pouplard S, Spitaliéry R, Grégoire A (2013) Nest-box size influences where secondary-cavity exploiters roost and nest: a choice experiment. J Ornithol 154:563-566. https://doi.org/10.1007/s10336-012-0919-y

Lima CC, Garcia CM (2016) Pre- and post-experimental manipulation assessments confirm the increase in number of birds due to the addition of nest boxes. PeerJ 4:e1806. https://doi.org/10.7717/peerj.1806

Lowther PE (2012) Does nest-box size impact clutch size of house sparrows? Wilson J Ornithol 124(2):384-389. https://doi.org/10.1676/11-166.1

Lumsden HG (1976) Choice of nestboxes by starlings. Wilson Bull 88:665-666

Mainwaring MC, Reynolds SJ, Weidinger K (2015) The influence of predation on the location and design of nests. In: Deeming DC, Reynolds SJ (eds) Nests, eggs, \& incubation: new ideas about avian reproduction. Oxford University Press, Oxford, pp 50-64

Mänd R, Leivits A, Leivits M, Rodenhouse NL (2009) Provision of nestboxes raises the breeding density of Great Tits Parus major equally in coniferous and deciduous woodland. Ibis 151(3):487-492. https:// doi.org/10.1111/j.1474-919X.2009.00929.x

Marzluff JM (2001) Worldwide urbanization and its effects on birds. In: Marzluff JM, Bowman R, Donnelly R (eds) Avian Conservation and Ecology in and Urbanizing World. Springer, US, Boston, pp 19-47

Mazgajski TD (2003) Nestsite choice in relation to the presence of old nests and cavity depth in the starling Sturnus vulgaris. Ethol Ecol Evol 15(3):273-281. https://doi.org/10.1080/08927014.2003.9522672

Mazgajski TD (2009) Breeding success of hole-nesting birds - effects of nest sites characteristics and predators avoidance strategies. Wiadomości Ekologiczne 55:159-183 
Maziarz M, Wesołowski T, Hebda G, Cholewa M, Broughton RK (2015) Breeding success of Great Tits Parus major in relation to attributes of natural nest-cavities in a primeval forest. J Ornithol $157: 343-354$

Merino S, Potti J (1995) Pied flycatchers prefer to nest in clean nest boxes in an area with detrimental nest ectoparasites. Condor 97:828-831

Milligan MC, Dickinson JL (2016) Habitat quality and nest-box occupancy by five species of oak woodland birds. Auk 133(3):429-438. https://doi.org/10.1642/AUK-15-187.1

Mine K, Yamada A, Nanri T, Maruyama K, Nakamura H, Saigusa M (2014) Effect of nestbox provisioning on breeding density of dollarbirds (Eurystomus orientalis). Pac Sci 68(3):365-374. https://doi.org/10. 2984/68.3.6

Minot EO, Perrins CM (1986) Interspecific interference competition-nest sites for Blue and Great Tits. J Anim Ecol 55:331-350. https://doi.org/10.2307/4712

Monti F, Nelli L, Catoni C, Dell'Omo G (2019) Nest box selection and reproduction of European Rollers in Central Italy: a 7-year study. Avian Res 10:13. https://doi.org/10.1186/s40657-019-0150-0

Moudrá L, Zasadil P, Moudrý V, Šálek M (2018) What makes new housing development unsuitable for house sparrows (Passer domesticus)? Landscape Urban Plan 169:124-130

Newton I (1994) The role of nest sites in limiting the numbers of hole-nesting birds: A review. Biol Conserv 70(3):265-276

Newton I (1998) Population Limitation in Birds. Academic Press, San Diego

Nilsson M, Berglund B (2006) Soundscape quality in suburban green areas and city parks. Acta Acust United Ac 92:903-911

Perrins CM (1979) British tits. Collins, London

Pirio M, Andersson A, Åkesson S (2015) Successful shared breeding in anartificial nest-box by Common Swift Apus apus and Common Redstart Phoenicurus phoenicurus. Ornis Svecica 25:105-108

Remm J, Lõhmus A, Remm K (2006) Tree cavities in riverine forests: What determines their occurrence and use by hole-nesting passerines? Forest Ecol Manag 221(1-3):267-277. https://doi.org/10.1016/j. foreco.2005.10.015

Reynolds SJ, Ibáñez-Álamo JD, Sumasgutner P, Mainwaring MC (2019) Urbanisation and nest building in birds: a review of threats and opportunities. J Ornithol 160:841-860. https://doi.org/10.1007/ s10336-019-01657-8

Riddington R, Gosler AG (1995) Differences in reproductive success and parental qualities between habitats in the Great Tit Parus major. Ibis 137:371-378

Rodríguez J, Avilés JM, Parejo D (2011) The value of nestboxes in the conservation of Eurasian Rollers Coracias garrulus in southern Spain. Ibis 153(4):735-745. https://doi.org/10.1111/j.1474-919X. 2011.01161.x

Rosin ZM, Skórka P, Pärt P, Żmihorski M, Ekner-Grzyb A, Kwieciński Z, Tryjanowski P (2016) Villages and their old farmsteads are hot spots of bird diversity in agricultural landscapes. J Appl Ecol 53:1363-1372. https://doi.org/10.1111/1365-2664.12715

Rosin ZM, Hiron M, Żmihorski M, Szymański P, Tobolka M, Pärt T (2020) Reduced biodiversity in modernized villages: A conflict between sustainable development goals. J Appl Ecol 57(3):467475. https://doi.org/10.1111/1365-2664.13566

Rubenser H (2012) Die Dohle (Corvus monedula) im Linzer Stadtgebiet. Verbreitung und Schutzmaßnahmen für den Vogel des Jahres 2012 (Jackdaw (Corvus monedula) in the city of Linz. Distribution and protection measures for the bird of the year 2012). Zeitschrift für Ökologie, Natur - und Umweltschutz 34(4):24-25

Sánchez S, Cuervo JJ, Moreno E (2007) Suitable cavities as a scarce resource for both cavity and noncavity nesting birds in managed temperate forests. A case study in the Iberian Peninsula. Ardeola 54(2):261-274

Schaaf AA, de la Peña MR (2020) Bird nest orientation and local temperature: an analysis over three decades. Ecology 00(00):e03042. https://doi.org/10.1002/ecy.3042

Schaaf AA, Garcia CG, Greeney HF (2019) Nest orientation in closed nests of Passeriformes across a latitudinal gradient in the Southern Neotropic. Acta Ornithol 54:265-270

Schaub T, Meffert PJ, Kerth G (2016) Nest-boxes for Common Swifts Apus apus as compensatory measures in the context of building renovation: efficacy and predictors of occupancy. Bird Conserv Int 26(2):164-176. https://doi.org/10.1017/s0959270914000525

Schmidt K (1999) In SW-Thüringen realisierte Schutzmaßnahmen für Dohlen Corvus monedula und der en Einfluss auf den Brutbestand dieser gefährdeten Vogelart (Protective measures for jackdaws Corvus monedula and the influence on the breeding population of this endangered bird species implemented in SW-Thuringia). Anz Ver Thüringer Ornithol 3:213-224 
Scholl I (ed) (2004) Nistplätze für Mauer- und Alpensegler: Praktische Informationen rund um Baufragen (Nesting sites for Common Swift and Alpine Swift: Practical information about construction issues). Iris Scholl Ver\&Oek, Uster

Serrano-Davies E, Barrientos R, Sanz JJ (2017) The role of nest-box density and placement on occupation rates and breeding performance: a case study with Eurasian Blue Tits. Ornis Fennica 94:21-32

Shaw LM, Chamberlain D, Evan M (2008) The House Sparrow Passer domesticus in urban areas: reviewing a possible link between post-decline distribution and human socioeconomic status. J Ornithol 149:293-299. https://doi.org/10.1007/s10336-008-0285-y

Slagsvold T (1975) Competition between the Great Tit Parus major and the Pied Flycatcher Ficedula hypoleuca in the breeding season. Ornis Scand 6:179-190. https://doi.org/10.2307/3676230

Sokal RR, Rohlf FJ (eds) (2012) Biometry: the principles and practice of statistics in biological research, 4td edn. WH Freeman and Company, New York

Stanback M, Dervan A (2001) Within-season nest-site fidelity in eastern bluebirds: disentangling effects of nest success and parasite avoidance. Auk 118:743-745

Sumasgutner P, Nemeth E, Tebb G, Krenn HW, Gamauf A (2014a) Hard times in the city - Attractive nest sites but insufficient food supply lead to low reproductive rates in a bird of prey. Front Zool $11: 48$

Sumasgutner P, Schulze CH, Krenn HW, Gamauf A (2014b) Conservation related conflicts in the nestsite selection of the Eurasian Kestrel (Falco tinnunculus) and the distribution of its avian prey. Landscape Urban Plan 127:94-103. https://doi.org/10.1016/j.landurbplan.2014.03.009

TIBCO Software Inc (2020) Data Science Textbook. https://docs.tibco.com/data-science/textbook. Accessed 17 July 2020

Tomasevic JA, Marzluff JM (2017) Cavity nesting birds along an urban-wildland gradient: is human facilitation structuring the bird community? Urban Ecosyst 20:435-448. https://doi.org/10.1007/ s1 1252-016-0605-6

Tomiałojć L (1980) Kombinowana odmiana metody kartograficznej do liczenia ptaków lęgowych (Combined variety of the cartographic method for counting breeding birds). Notatki Ornitologiczne 21:33-54

Tryjanowski P, Murawiec S (2021) Ornitologia terapeutyczna. Bogucki Wydawnictwo Naukowe

Unger C, Kurth K (2010) Untersuchungen zur Brutbiologie und zur Habitat wahl bei der Dohle Coloeus monedula im Landkreis Hildburghausen, Südthüringen (Studies on breeding biology and habitat selection of the jackdaw Coloeus monedula in the district of Hildburghausen, South Thuringia.). Anz Ver Thüringer Ornithol 7:95-107

van Balen JH, Booy CJH, Van Franeker JA, Osieck ER (1982) Studies on hole-nesting birds in natural nest sites: 1. Availability and occupation of natural nest sites. Ardea 70:1-24

von Post M, Smith HG (2015) Effects on rural House Sparrow and Tree Sparrow populations by experimental nest-site addition. J Ornithol 156:231-237. https://doi.org/10.1007/s10336-014-1117-X

Wesołowski T (2007) Lessons from long-term hole-nester studies in a primeval temperate forest. J Ornithol 148(Suppl. 2):395-405

Wesołowski T, Martin K (2018) Tree holes and hole-nesting birds in European and North American Forests. In: Mikusiński G, Roberge J-M, Fuller RJ (eds) Ecology and conservation of forest birds. Cambridge University Press, Cambridge, pp 79-134

Wesołowski T, Rowiński P (2012) The breeding performance of Blue Tits Cyanistes caeruleus in relation to the attributes of natural holes in a primeval forest. Bird Study 59:437-448

Wiebe KL (2011) Nest sites as limiting resources for cavity-nesting birds in mature forest ecosystems: A review of the evidence. J Field Ornithol 82:239-248

Ye P, Yang C, Liang W (2019) Nest site availability and niche differentiation between two cavity-nesting birds in time and space. Ecol Evol 9(20):11904-11910. https://doi.org/10.1002/ece3.5698

Publisher's Note Springer Nature remains neutral with regard to jurisdictional claims in published maps and institutional affiliations. 